REFLEKSI EDUKATIKA : Jurnal Ilmiah Kependidikan

Volume 11 Nomor 1 Desember 2020

ISSN: 2087-9385 (print) dan 2528-696X (online) http://jurnal.umk.ac.id/index.php/RE

\title{
EVALUASI PROGRAM EKSTRAKURIKULER DI SDN CANDIREJO KABUPATEN SEMARANG
}

\section{Winny Rosa Damayanti, Yari Dwikurnaningsih}

\author{
Universitas Kristen Satya Wacana, Indonesia \\ Email: rosawinnydamayanti@gmail.com
}

\section{Info Artikel}

Sejarah Artikel:

Diserahkan 10 Mei 2020

Direvisi 25 November 2020

Disetujui 26 November 2020

\section{Keywords:}

context,

input,

process,

product of extracurricular

program.

\begin{abstract}
The purpose of this research was to evaluate about context, input, process, and product of extracurricular program in SDN Candirejo Kabupaten Semarang.

This type of research was evaluation research by CIPP model. This research method used descriptive qualitative method. This research fosused on extracurricular program in SDN Candirejo Kabupaten Semarang. Data collection techniques used interview, observation and documentation study. Data validity techniques used tringulation of technique and source. Data analysis steps were data collection, data reduction, data display and data verification.

The result of this research were (1) The context aspects was in accordance with Extracurricular Technical Guide in Elementary School, such as extracurricular program background was to facilitate and develop student's potential, talents and interests, and to cultivate student's mentally and self-confidence. (2) Input aspects included planning, human resource involved, and financing were adequate and in accordance with Extracurricular Technical Guide in Elementary School. Extracurricular facilities need to be improved; (3) Process aspects were extracurricular program implementation included program mechanism, program implementation, facilities management, human resource and financing were in accordance with program planning that has been prepared which reffering to Extracurricular Technical Guide in Elementary School. (4) Product aspects were increased student's skill, the school often got requests to perform at events, received more than 35 students every year; (5) supporting factors such as team work, commitment and competent human resource. Inhibiting factors such as limited partners, extracurricular class was not yet available.
\end{abstract}

\begin{abstract}
Abstrak
Tujuan penelitian ini adalah untuk mengevaluasi konteks, input, proses, produk program ekstrakurikuler di SDN Candirejo Kabupaten Semarang.

Metode penelitian ini deskriptif kualitatif. Jenis penelitian ini yaitu penelitian evaluasi model CIPP (Context, Input, Process, Product). Fokus penelitian ini yaitu program ekstrakurikuler di SDN Candirejo Kabupaten Semarang. Teknik pengumpulan data menggunakan wawancara, observasi, dan studi dokumentasi. Teknik keabsahan data menggunakan triangulasi teknik dan sumber. Tahapan analisis data antara lain koleksi data, reduksi data, display data, dan verifikasi data.

Hasil penelitian menunjukkan bahwa (1) Aspek konteks sesuai dengan Panduan Teknis Ekstrakurikuler di SD yaitu latar belakang program esktrakurikuler yaitu untuk memfasilitasi dan mengembangkan potensi, bakat, dan minat peserta didik, serta menumbuhkan mental dan memupuk percaya diri peserta didik. (2) Aspek input yang meliputi perencanaan, sumber daya manusia yang terlibat, pembiayaan sudah memadai dan sesuai dengan Pedoman Teknis Ekstrakurikuler di SD. Pada bidang sarana prasarana ekstrakurikuler di sekolah perlu ditingkatkan; (3) Aspek proses, pelaksanaan program ekstrakurikuler meliputi mekanisme program, pelaksananaan program, pengelolaan sarana prasarana, ketenagaan dan pembiayaan sesuai dengan perencanaan program yang telah disusun yang mengacu pada Panduan Teknis Ekstrakurikuler di SD; (4) Aspek produk, meningkatnya keterampilan peserta didik, sering mendapatkan permintaan untuk menampilkan di beberapa acara, menerima rata-rata 35 peserta didik baru setiap tahunnya; (5) Faktor pendukung Kerjasama, komitmen, SDM yang berkompeten. Faktor penghambat yaitu mitra yang terbatas, belum ada ruang khusus untuk ekstrakurikuler.
\end{abstract}

(C) 2020 Universitas Muria Kudus 
Winny Rosa Damayanti, Yari Dwikurnaningsih

EVALUASI PROGRAM EKSTRAKURIKULER DI SDN CANDIREJO KABUPATEN SEMARANG

REFLEKSI EDUKATIKA : Jurnal Ilmiah Kependidikan, Volume 11, Nomor 1, Desember 2020, hlm. 59-69

\section{PENDAHULUAN}

Untuk mengembangkan potensi peserta didik, diperlukan suatu wadah yang dapat menampung bakat minat peserta didik. Menurut Undang-undang Nomor 20 Tahun 2003 Pasal 12 ayat 1 (b) menyatakan bahwa setiap peserta didik pada setiap satuan pendidikan berhak untuk mendapatkan pelayanan pendidikan sesuai dengan bakat, minat, dan kemampuannya. Salah satu program kegiatan yang dapat menunjang pengembangan potensi sesuai dengan bakat, minat, dan kemampuan peserta didik adalah ekstrakurikuler. Ekstrakurikuler adalah kegiatan yang dilaksanakan di luar jam pelajaran sebagai wadah dalam menyalurkan potensi, minat, dan bakat peserta didik, agar memiliki keterampilan dan kepribadian yang matang, dan mempersiapkan peserta didik menjadi manusia yang unggul, berkualitas dan berdaya saing agar dapat menjawab tantangan-tantangan di masa depan.

Menurut Permendikbud Nomor 62 Tahun 2014 tentang Kegiatan Ekstrakurikuler pada Pendidikan Dasar dan Menengah Pasal 1 ayat 1, kegiatan ekstrakurikuler adalah kegiatan yang dilakukan oleh peserta didik di luar jam belajar kegiatan intrakurikuler dan kegiatan ko kurikuler, di bawah bimbingan dan pengawasan satuan pendidikan. Undang-undang Nomor 62 Tahun 2014 Tentang Kegiatan Ekstrakurikuler Pada Pendidikan Dasar Dan Pendidikan Menengah Pasal 2 bahwa Kegiatan Ekstrakurikuler diselenggarakan dengan tujuan untuk mengembangkan potensi, bakat, minat, kemampuan, kepribadian, kerjasama, dan kemandirian peserta didik secara optimal dalam rangka mendukung pencapaian tujuan pendidikan nasional.

Penelitian yang dilakukan oleh Natalie Fischer and Désirée Theis (2014) menyebut bahwa bahwa kegiatan ekstrakurikuler memberikan dampak yang signifikan dengan motivasi belajar peserta didik dan dapat meningkatkan prestasi akademik peserta didik melalui kegiatan yang berkualitas. Berpartisipasi dalam kegiatan ekstrakurikuler di sekolah dapat melindungi remaja terhadap perkembangan negatif dengan memberikan lebih banyak kesempatan membuat keputusan dan pilihan dan untuk berhubungan ke orang lain (keterkaitan). Dapat kita ketahui bahwa ekstrakurikuler cenderung memberikan pengaruh positif kepada peserta didik, baik untuk meningkatkan keterampilan, menambah semangat dan membentuk karakter yang positif pada peserta didik. Sementara itu riset Alfiana, Djariyo, dan Artharina (2017) menyebut kegiatan ekstrakurikuler membatik yang telah dilaksanakan di SD N Mantingan memiliki peran terhadap kemampuan membatik seni rupa sehingga menghasilkan berbagai karya seni batik. Kemampuan membatik seni rupa antara lain unsur dan prinsip seni yang diajarkan oleh pelatih atau guru mampu membuat siwa dapat berkreasi, berkarya, mengembangkan kreativitas, mengungkapkan perasaan, bakat, motivasi dan mandiri.

Demi menunjang kelancaran kegiatan ekstrakurikuler maka diperlukan evaluasi kegiatan ekstrakurikuler. Hasil evaluasi digunakan untuk pengambilan keputusan dalam rangka perbaikan pada pelaksanaan kegiatan selanjutnya. Evaluasi program adalah upaya untuk mengetahui efektivitas komponen program dalam mendukung pencapaian tujuan program (Arikunto dan Jabar, 2014). Tujuan evaluasi program adalah untuk menentukan apakah layanan atau intervensinya telah mencapai tujuan yang ditetapkan dan supaya dapat diketahui dengan pasti apakah pencapaian hasil, kemajuan dan hambatan yang dijumpai dalam pelaksanaan program dapat dinilai dan dipelajari untuk perbaikan pelaksanaan program di masa yang akan mendatang (Wirawan, 2012).

Undang-undang Nomor 62 Tahun 2014 Tentang Kegiatan Ekstrakurikuler Pada Pendidikan Dasar Dan Pendidikan Menengah Pasal 7 bahwa (2) Satuan pendidikan melakukan evaluasi Program Kegiatan Ekstrakurikuler pada setiap akhir tahun ajaran untuk mengukur ketercapaian tujuan pada setiap indikator yang telah ditetapkan, dan (3) Hasil evaluasi Program Kegiatan Ekstrakurikuler sebagaimana dimaksud pada ayat (2) digunakan untuk penyempurnaan program kegiatan ekstrakurikuler tahun ajaran berikutnya. Tujuan evaluasi kegiatan ekstrakurikuler dimaksudkan untuk mengumpulkan data atau informasi mengenai tingkat keberhasilan yang dicapai. Penilaian dapat dilakukan untuk menetapkan tingkat keberhasilan peserta didik pada tahap-tahap tertentu dan untuk jangka waktu tertentu berkenaan dengan proses dan hasil kegiatan ekstrakurikuler (Burhanuddin, 2014).

Penelitian Ramdhoni (2019) menyatakan bahwa dilihat dari perencanaan, tujuan dan juga kesiapan sarana dan prasarana yang digunakan untuk kegiatan pramuka. Pada aspek masukan dapat disimpulkan bahwa ektrakurikuler pramuka di MTs Al-Ishlah Panambangan Kecamatan Sedong Kabupaten Cirebon merupakan ekstrakurikuler yang wajib di ikuti oleh siswa kelas VII. Pada aspek proses kegiatan pramuka di MTs Al-Ishlah yang rutin dilaksanakan sesuai dengan materi, permainan yang sangat sesuai dengan kepanduan. Pada aspek produk terdapat perubahan sikap dan juga pembentukan karakter siswa melalui kegiatan pramuka yang cukup besar dampaknya, dilihat dari besarnya 
Winny Rosa Damayanti, Yari Dwikurnaningsih

EVALUASI PROGRAM EKSTRAKURIKULER DI SDN CANDIREJO KABUPATEN SEMARANG

REFLEKSI EDUKATIKA : Jurnal Ilmiah Kependidikan, Volume 11, Nomor 1, Desember 2020, hlm. 59-69

persentase mengenai dampak kegiatan pramuka yang mana siswa dapat mengimplementasikan nilai-nilai yang terkandung ke dalam kehidupan sehari-hari baik di sekolah maupun diluar sekolah.

SDN Candirejo Kabupaten Semarang memiliki beberapa program kegiatan ekstrakurikuler antara lain ekstrakurikuler pramuka, tari, pencak silat, renang, drumband dan rebana yang belum pernah dievaluasi. Peneliti melakukan penelitian evaluasi program kegiatan ekstrakurikuler di SDN Candirejo Kabupaten Semarang, meliputi aspek konteks, input, proses dan produk. Model evaluasi yang akan digunakan dalam penelitian ini adalah model evaluasi $C I P P$ (Context, Input, Process, Product). Tujuan penelitian evaluasi program kegiatan ekstrakurikuler di SDN Candirejo Kabupaten Semarang adalah untuk mengevaluasi aspek context, input, process, dan product program kegiatan ekstrakurikuler dan memberi rekomendasi kepada SDN Candirejo Kabupaten Semarang mengenai implementasi program kegiatan ekstrakurikuler setelah mendapatkan hasil evaluasi konteks, input, proses dan produk program kegiatan ekstrakurikuler di SDN Candirejo Kabupaten Semarang.

\section{METODE PENELITIAN}

Jenis penelitian ini yaitu penelitian evaluasi dengan metode deskriptif kualitatif. Penelitian ini bertujuan untuk menganalisis atau mengevaluasi pelaksanaan program ekstrakurikuler di SDN Candirejo. Model yang digunakan dalam penelitian ini adalah evaluasi model CIPP (context, input, proses, product). Adapun objek yang diteliti antara lain aspek konteks meliputi kebutuhan program ekstrakurikuler, tujuan ekstrakurikuler serta sasaran program ekstrakurikuler.

Pada aspek input meliputi perencanaan program ekstrakurikuler, pembiayan, sarana prasarana dan sumberdaya manusia program ekstrakurikuler. Aspek proses meliputi mekanisme pelaksanaan program, pelaksanaan program ekstrakurikuler, pengelolaan sarana dan prasarana, pengelolaan ketenagaan, dan pembiayaan program kegiatan ekstrakurikuler. Aspek produk meliputi rapor peserta didik, prestasi peserta didik dan perkembangan potensi bakat minat peserta didik. Faktor pendukung dan penghambat program ekstrakurikuler di SDN Candirejo Kabupaten Semarang.

Penelitian ini dilaksanakan di SDN Candirejo Kabupaten Semarang. Berdasarkan data yang diperoleh dari wawancara dengan kepala sekolah SDN Candirejo Kabupaten Semarang menunjukkan bahwa SDN Candirejo Kabupaten Semarang telah mengadakan kegiatan ekstrakurikuler wajib yaitu pramuka, dan ekstrakurikuler pilihan yaitu pencak silat, tari, drum band dan renang. Waktu pelaksanaan penelitian ini yakni 3 bulan, yaitu Maret-April 2020.

Penelitian evaluasi program kegiatan ekstrakurikuler di SDN Candirejo Kabupaten Semarang menggunakan teknik pengumpulan data berupa wawancara, observasi, dan studi dokumentasi. Sumber informasi dalam penelitian ini yang menghasilkan data penelitian meliputi: Kepala SDN Candirejo Kabupaten Semarang, penanggungjawab kegiatan ekstrakurikuler SDN Candirejo Kabupaten Semarang, pelatih ekstrakurikuler Candirejo Kabupaten Semarang, dan komite SDN Candirejo Kabupaten Semarang.

Objek dalam penelitian ini yakni 1) Program Kegiatan Ekstrakurikuler, 2) Evaluasi Program, dan c) Model CIPP (context, input, process, product). Evaluasi program dalam penelitian ini dimaksudkan untuk mengevaluasi pelaksanaan program kegiatan ekstrakurikuler dengan menggunakan model evaluasi CIPP (context, input, process, product).

Penelitian evaluasi program kegiatan ekstrakurikuler di SDN Candirejo Kabupaten Semarang menggunakan teknik pengumpulan data berupa wawancara, observasi, dan studi dokumentasi. Teknik analisis data dalam penelitian ini adalah deskriptif kualitatif. Teknik yang digunakan untuk menguji keabsahan sumber yakni teknik triangulasi sumber. Pengujian dilakukan kepada kepala sekolah, penanggung jawab dan pelatih atau pendamping kegiatan ekstrakurikuler. Triangulasi teknik untuk uji validitas data. Dalam penelitian ini triangulasi teknik dilakukan dengan mengecek data kepada sumber yang sama dengan teknik yang berbeda.

\section{HASIL DAN PEMBAHASAN}

\begin{tabular}{llllr} 
1. Evaluasi & \multicolumn{2}{c}{ Konteks } & \multicolumn{2}{c}{$\begin{array}{c}\text { Program } \\
\text { Ekstrakurikuler di SDN }\end{array}$} \\
$\begin{array}{l}\text { Kabupaten Semarang } \\
\text { Berdasarkan wawancara }\end{array}$ & dan & studi
\end{tabular}
dokumentasi diketahui bahwa latar belakang penyelenggaraan program ekstrakurikuler adalah kesadaran atas kewajiban sekolah untuk melaksanakan pendidikan yang dapat mengembangkan potensi sesuai dengan karakteristik peserta didik. Sekolah memiliki tugas 
Winny Rosa Damayanti, Yari Dwikurnaningsih

EVALUASI PROGRAM EKSTRAKURIKULER DI SDN CANDIREJO KABUPATEN SEMARANG

REFLEKSI EDUKATIKA : Jurnal Ilmiah Kependidikan, Volume 11, Nomor 1, Desember 2020, hlm. 59-69

untuk membekali pengetahuan dan keterampilan bidang akademik dan non akademik pada peserta didik sehingga diperlukan adanya suatu program untuk memfasilitasi, menggali dan mengembangkan potensi, bakat dan minat peserta didik di sekolah yaitu melalui ekstrakurikuler. Hal tersebut sesuai dengan Undang-undang Nomor 20 Tahun 2003 Pasal 12 ayat 1 (b) menyatakan bahwa setiap peserta didik pada setiap satuan pendidikan berhak untuk mendapatkan pelayanan pendidikan sesuai dengan bakat, minat, dan kemampuannya.

Penentuan jenis ekstrakurikuler yang diselenggarakan di SDN Candirejo Kabupaten Semarang didasarkan pada analisis kebutuhan melalui observasi dan rapat antara kepala sekolah, tenaga pendidik dan kependidikan, serta komite sekolah terhadap adanya potensi paling banyak pada peserta didik, pandangan masyarakat tentang ketersediaan ekstrakurikuler di sekolah, ekstrakurikuler yang identik sering dipakai oleh sekolah lain dan didasarkan pada kekuatan sarana prasarana dan dana sekolah. Sejalan dengan penelitian yang dilakukan oleh Munastiwi (2018) bahwa merencanakan kebutuhan ekstrakurikuler dilakukan dengan cara menganalisis hasil observasi, wawancara, kuesioner dan dokumentasi. Fungsi analisis kebutuhan yaitu mengidentifikasi kebutuhan, bakat minat anak, memetakan sarana dan prasarana serta SDM pengajar.

Tahapan ini sangat penting dilakukan untuk mengetahui daya dukung lembaga dalam melaksanakan kegiatan ekstrakurikuler. Setelah dilakukan analisis kebutuhan maka dapat diketahui bahwa diperlukan program ekstrakurikuler yang dapat mengembangkan potensi di bidang kesenian dan olahraga seperti pencak silat, renang, tari, drumband dan rebana. Hal ini sesuai dengan Panduan Teknik Ekstrakurikuler di SD (Kemendikbud, 2016) bahwa kebutuhan dan minat peserta didik dianalisis yang selanjutnya dikembangkan ke dalam kegiatan ekstrakurikuler yang bermanfaat positif bagi siswa.

Berdasarkan wawancara dengan penanggung jawab salah satu program ekstrakurikuler bahwa tujuan program ekstrakurikuler di SDN Candirejo Kabupaten Semarang secara garis besar adalah memfasilitasi dan mengembangkan potensi, bakat dan minat peserta didik, dan memberikan bekal berupa keterampilan yang dapat mengasah softskill peserta didik. Selain itu, program ekstrakurikuler yang diselenggarakan dapat membentuk karakter positif yang kuat dalam diri peserta didik, seperti religius, bertanggung jawab, mandiri, empati, kerjasama dan cinta tanah air (Ismaya dan Romadlon, 2017; Ardianti, Wanabuliandari, Kanzunnudin, 2019) . Hal tersebut sesuai dengan tujuan ekstrakurikuler yang tertuang dalam Panduan Teknis Kegiatan Ekstrakurikuler di SD (Kemendikbud, 2016) bahwa kegiatan ekstrakurikuler harus dapat mengembangkan potensi, bakat dan minat peserta didik dalam upaya pembinaan pribadi menuju pembinaan manusia seutuhnya. Sejalan dengan penelitian yang dilakukan oleh Riitta-Leena Metsäpelto and Lea Pulkkinen (2014) menunjukkan bahwa kegiatan ekstrakurikuler dan kegiatan terorganisasi lainnya dapat memberikan berbagai macam pengalaman dan interaksi yang lebih berkualitas antara peserta didik, orang dewasa dan peserta didik di sekolah, yang dapat membangun sosioemosional yang baik.

Program ekstrakurikuler di SDN Candirejo Kabupaten Semarang berupaya untuk dapat melatih mental dan memupuk percaya diri pada diri peserta didik. Hal ini selaras dengan fungsi ekstrakurikuler (Kemendikbud, 2016) bahwa ekstrakurikuler memiliki fungsi pengembangan yaitu untuk mendukung perkembangan personal peserta didik melalui perluasan minat, pengembangan potensi, dan pemberian kesempatan untuk pembentukan karakter dan pelatihan kepemimpinan.

Hal ini sejalan dengan Undang-undang Nomor 20 Tahun 2003 tentang Sistem Pendidikan Nasional Pasal 3 adalah mengembangkan potensi peserta didik agar menjadi manusia yang beriman dan bertakwa kepada Tuhan Yang Maha Esa, berakhlak mulia, sehat, berilmu, cakap, kreatif, mandiri, dan menjadi warga negara yang demokratis serta bertanggung jawab.

Sasaran program ekstrakurikuler adalah peserta didik. Sejalan dengan penelitian yang dilakukan oleh Natalie Fischer and Désirée Theis (2014) bahwa sasaran utama kegiatan ekstrakurikuler adalah seluruh peserta didik. Menurut Panduan Teknis Ekstrakurikuler di SD (Kemendikbud, 2016) bahwa sasaran program ekstrakruikuler adalah peserta didik Sekolah Dasar (SD), Sekolah Menengah Pertama (SMP), dan Sekolah Menengah Atas (SMA). Pada penelitian ini sasaran program adalah peserta didik sekolah dasar (SD).

SDN Candirejo Kabupaten Semarang mewajibkan bagi peserta didik kelas 1 sampai dengan kelas 5 untuk mengikuti ekstrakurikuler wajib yaitu pramuka. Berkaitan dengan ekstrakurikuler wajib pramuka, Ismaya (2013) menyebut bahwa Applicability of Curriculum 
Winny Rosa Damayanti, Yari Dwikurnaningsih

EVALUASI PROGRAM EKSTRAKURIKULER DI SDN CANDIREJO KABUPATEN SEMARANG

REFLEKSI EDUKATIKA : Jurnal Ilmiah Kependidikan, Volume 11, Nomor 1, Desember 2020, hlm. 59-69

2013, the Boy Scouts as an extra-curricular mandates compulsory in schools, from elementary school to high school, further strengthening the role of the Scout Movement in an effort to prepare, establish and develop the character of the Indonesian people, especially the youth that was born 2045 Golden Generation Indonesian whose character, quality and has competitive edge in the local, national and global. Lebih lanjut Ismaya (2012) menemukan pramuka mampu membentuk karakter anggota ambalan Jodhipati-Candrasari sehingga memiliki mental baja dan menjadi pribadi yang santun, sukses dalam menjalani hidupnya, memiliki semangat persatuan dan kesatuan serta jiwa sosial yang tinggi kepada sesama hidup, juga rasa handarbeni dan hangkrukebi terhadap ambalan Jodhipati-Candrasari.

Ekstrakurikuler wajib tambahan yaitu ekstrakurikuler drum band bagi peserta didik kelas 4 dan 5, sedangkan kelas lain tidak diwajibkan mengikuti ekstrakruikuler drum band. Kemudian peserta didik dibebaskan memilih ekstrakurikuler pilihan yang tersedia antara lain pencak silat, renang, tari dan rebana sesuai dengan potensi, bakat dan minat peserta didik. Apabila peserta didik memiliki potensi, bakat dan minat di bidang seni musik, SDN Candirejo Kabupaten Semarang menyediakan ekstrakurikuler drum band dan rebana. Bagi peserta didik yang memiliki potensi, bakat dan minat di bidang seni tari, maka peserta didik dapat memilih ekstrakurikuler tari. Bagi peserta didik yang memiliki potensi, bakat dan minat di bidang olahraga, maka peserta didik dapat memilih ekstrakurikuler pencak silat dan renang. Ekstrakurikuler pilihan bebas dipilih oleh peserta didik tanpa batasan maksimal dalam mengikuti beberapa ekstrakurikuler selama masih ada kuota menerima peserta ekstrakurikuler tersebut.

\section{Evaluasi Input Program Ekstrakurikuler di SDN Candirejo Kabupaten Semarang

Berdasarkan wawancara dan studi
dokumentasi bahwa pada bidang perencanaan program ekstrakurikuler SDN Candirejo Kabupaten Semarang meliputi jenis ekstrakurikuler, latar belakang, tujuan, sasaran, jadwal kegiatan, rangkaian materi yang diajarkan, tempat kegiatan, sarana prasarana yang tersedia, dan anggaran. Hal ini sudah sesuai dengan Panduan Teknis Ekstrakurikuler di SD bahwa penyusunan program terdiri dari 1) Jenis kegiatan, 2) Waktu kegiatan, 3) Sasaran, 4) Rangkaian kegiatan, 5) Tempat kegiatan, 6) Peralatan yang digunakan, 7)
Pelaksana program, 8) Pengorganisasian, dan 9) Anggaran (Kemendikbud, 2016).

Pada bidang sumber daya manusia yang dilibatkan adalah kepala sekolah, tenaga pendidik dan tenaga kependidikan (pustakawan dan penjaga sekolah), serta pelatih dan komite sekolah. Kepala sekolah sebagai penanggungjawab sekolah, guru sebagai penanggungjawab program, pendamping dan pembimbing ekstrakurikuler, pelatih sebagai pembimbing dan komite berperan sebagai perencana dan pengawas. SDN Candirejo Kabupaten Semarang menggunakan pelatih dari luar pada ekstrakurikuler drum band dan pencak silat, serta pustakawan dan penjaga sekolah menjalankan fungsi pendampingan kegiatan ekstrakurikuler. Komite sekolah dilibatkan ketika menganalisis kebutuhan dan penentuan jenis ekstrakurikuler. Hal tersebut sebagian besar selaras dengan Pedoman Teknis Ekstrakurikuler di SD bahwa sumber daya manusia yang dilibatkan telah sesuai panduan dan memiliki tanggungjawabnya masing-masing sesuai dengan fungsinya (Kemendikbud, 2016).

Dalam pemilihan penanggungjawab dan pelatih didasarkan pada observasi kepala sekolah dan rapat antara kepala sekolah, tenaga pendidik dan kependidikan terhadap kompetensi tenaga pendidik, kependidikan dan pelatih. Sejalan dengan penelitian Nurcahyo (2013) bahwa sebagian besar yang memiliki badan organisasi, kepala sekolah sebagai penanggung jawab terhadap seluruh kegiatan ekstrakurikuler dan dengan bantuan wakil kepala serta guru pendamping. Pelatih diambil secara kombinatif yaitu dari luar dan dalam sekolah karena dianggap melalui seleksi ini pelatih atau pengelola akan dapat lebih mengenal peserta didik dan lebih yang berkompetensi dalam menjalankan tugas dan kewajibannya

Dalam hal ini perlu ditingkatkan kembali peran komite sekolah dalam membuat perencanaan dan pengawasan terhadap program ekstrakurikuler di SDN Candirejo Kabupaten Semarang agar keberhasilan program ekstrakurikuler meningkat melalui saran dan masukan dari komite sekolah.

Pada bidang pembiayaan program berasal dari BOS (Bantuan Operasional Sekolah) tanpa memungut dana dari peserta didik kecuali ketika pentas tari, drum band dan rebana karena membutuhkan make up. Sehingga orang tua/wali murid berpartisipasi untuk mengusahakan make up dari diri sendiri. Honor pelatih juga berasal dari BOS. Hal ini sesuai dengan Panduan Teknis Ekstrakurikuler di SD (Kemendikbud, 2016) bahwa 
Winny Rosa Damayanti, Yari Dwikurnaningsih

EVALUASI PROGRAM EKSTRAKURIKULER DI SDN CANDIREJO KABUPATEN SEMARANG

REFLEKSI EDUKATIKA : Jurnal Ilmiah Kependidikan, Volume 11, Nomor 1, Desember 2020, hlm. 59-69

dana diperoleh dari sumber-sumber yang sesuai dengan aturan perundang-undangan.

Pada bidang sarana prasarana yang dibutuhkan untuk program ekstrakurikuler sudah cukup, akan tetapi perlu dilengkapi untuk alat musik pianika karena peserta didik diminta untuk membawa pianika pribadi. Menurut Panduan Teknis Ekstrakurikulerdi SD bahwa sarana prasarana disediakan oleh sekolah (Kemendikbud, 2016). Sehingga SDN Candirejo Kabupaten Semarang perlu meningkatkan lagi sarana prasarana yang belum terpenuhi.

Hasil penelitian menunjukkan bahwa sumber dana program ekstrakurikuler SDN Candirejo Kabupaten Semarang berasal dari BOS. Berbeda dengan hasil penelitian yang dilakukan oleh Nurcahyo (2013) bahwa sumber dana ekstrakurikuler di SMA/MAN/Sederajat seKabupaten Sleman berasal dari orang tua/wali murid. Dana atau keuangan digunakan untuk membayar pelatih dan pengelola, pengadaan sarana-prasarana olahraga, oprasional harian, biaya mengikuti suatu kejuaraan atau event, dan membayar sewa gedung.

\section{Evaluasi Proses Program Ekstrakurikuler di SDN Candirejo Kabupaten Semarang \\ 3.1 Mekanisme Pelaksanaan Program}

Berdasarkan wawancara dan studi dokumentasi bahwa mekanisme program ekstrakurikuler di SDN Candirejo Kabupaten Semarang yaitu melalui sosialisasi ekstrakurikuler oleh kepala sekolah dan guru kelas kepada peserta didik dan orang tua/wali murid ketika penerimaan rapor peserta didik, pertemuan orang tua/walimurid, grup paguyuban kelas dan ketika di kelas. Peserta didik yang ingin mengikuti ekstrakurikuler tertentu harus mengisi formulir kesediaan mengikuti ekstrakurikuler. SDN Candirejo Kabupaten Semarang mewajibkan peserta didik kelas 1 sampai dengan kelas 5 untuk mengikuti ekstrakurikuler pramuka, dan ekstrakurikuler drum band untuk kelas 4 dan kelas 5 berdasarkan kebijakan dari sekolah.

Perekrutan peserta ekstrakurikuler di SDN Candirejo Kabupaten Semarang tidak dilakukan sistem seleksi penerimaan peserta ekstrakurikuler, baik itu secara wawancara, kuesioner atau tes. Perekrutan peserta ekstrakurikuler di SDN Candirejo Kabupaten Semarang dilakukan dengan cara penyampaian informasi secara lisan oleh kepala sekolah, penanggungjawab dan guru kelas kepada peserta didik dan orang tua/wali murid.
Kemudian melakukan pendaftaran untuk mengikuti kegiatan ekstrakurikuler dengan mengisi formulir. Sehingga peserta didik yang lebih dulu mendaftar melalui formulir kesediaan mengikuti ekstrakurikuler yang dituju akan diterima selama kuota peserta ekstrakurikuler tersebut belum penuh.

Hal ini sejalan dengan sistem perekrutan pada penelitian Viningsih (2013) bahwa bahwa mekanisme rekuritmen peserta ekstrakurikuler dapat dilakukan dengan cara (1) penyampaian informasi secara tertulis tentang jenis kegiatan ekstrakurikuler yang disampaikan melalui selebaran yang dibagikan kepada peserta didik, (2) penyampaian informasi secara lisan, (3) melakukan pendaftaran untuk mengikuti kegiatan ekstrakurikuler dengan mengisi formulir, (4) melakukan seleksi/penempatan peserta menurut bidangnya, dimana terdapat pernyataan seleksi dilakukan berdasarkan bahan pendaftaran melalui formulir, (5) kesesuaian bidang ekstrakurikuler yang diikuti dengan bakat dan minat.

\subsection{Pelaksanaan Program Ekstrakurikuler}

Berdasarkan wawancara, observasi dan studi dokumentasi bahwa pada bidang pelaksanaan program ekstrakurikuler SDN Candirejo Kabupaten Semarang bahwa pelaksanaan ekstrakurikuler didasarkan pada program kerja ekstrakurikuler yang berisi pengembangan materi dan jadwal pelaksanaan kegiatan ekstrakurikuler. Materi kegiatan ekstrakurikuler disusun oleh pelatih pada saat awal semester atau 1 tahun dan disesuaikan dengan jadwal yang disepakati antara penanggungjawab dengan pelatih atau pendamping. Jadwal ekstrakurikuler berdasarkan diskusi antara penanggungjawab dengan pelatih. Ekstrakurikuler dilaksanakan diluar jam pelajaran dengan durasi 2 jam pelajaran.

Hal ini sejalan dengan Panduan Teknis Ekstrakurikuler di SD bahwa penjadwalan waktu kegiatan ekstrakurikuler sudah dirancang pada awal tahun atau semester dan diatur sedemikian rupa sehingga tidak menghambat pelaksanaan kegiatan kurikuler atau menyebabkan gangguan bagi peserta didik dalam mengikuti kegiatan ekstrakurikuler. Kegiatan ekstrakurikuler dilakukan di luar jam pelajaran kurikuler yang terencana, dan dapat dilakukan setiap hari atau waktu tertentu (Kemendikbud, 2016).

Penelitian Hanafi (2020) bahwa menyebut bahwa pelaksanaan kegiatan ekstrakurikuler broadcasting di SMKN 4 Kota Malang meliputi waktu pelaksanaan, pihak yang berperan dalam 
Winny Rosa Damayanti, Yari Dwikurnaningsih

EVALUASI PROGRAM EKSTRAKURIKULER DI SDN CANDIREJO KABUPATEN SEMARANG

REFLEKSI EDUKATIKA : Jurnal Ilmiah Kependidikan, Volume 11, Nomor 1, Desember 2020, hlm. 59-69

pembuatan program kerja, pelaksanaan pembuatan program kerja, dan juga pelaksanaan kegiatan ekstrakurikuler broadcasting.

\subsection{Pengelolaan Sarana Prasarana}

Berdasarkan observasi yang dilakukan peneliti bahwa sarana prasarana yang dikelola sesuai dengan Panduan Teknis Ekstrakurikuler di SD. Alat-alat yang dimiliki SDN Candirejo Kabupaten Semarang antara lain, ekstrakurikuler pramuka: tongkat, bendera, kompas, tali, semapur, peta buta Jawa Tengah, tanda dan identitas seragam pramuka dan peluit; ekstrakurikuler drum band: snare bass, bass drum, kuarto tom-tom, ballyra, cymbal, stik drum, tongkat dan bendera mayoret, dan seragam; ektrakurikuler rebana: rebana biang, hadroh, ketimpring, dor, dan kasidah

Berdasarkan observasi, fasilitas yang belum tersedia adalah alat musik pianika. Untuk mengatasi hal tersebut, peserta didik yang bertugas memainkan alat musik pianika diminta untuk membawa pianika pribadi peserta didik dari rumah ketika ekstrakurikuler drum band.

Pelaksanaan ekstrakurikuler dilaksanakan di halaman SDN Candirejo Kabupaten Semarang. Apabila peserta yang mengikuti kegiatan ekstrakurikuler terlalu banyak dan halaman sekolah tidak mencukupi untuk latihan, maka kegiatan dialihkan ke balai desa Candirejo. SDN Candirejo Kabupaten Semarang belum memiliki ruang lab yang dapat digunakan untuk melakukan kegiatan ekstrakuriler di dalam ruangan.

Solusi yang diambil oleh SDN Candirejo Kabupaten Semarang ketika situasi dan kondisi tidak memungkinkan untuk dilaksanakan kegiatan ekstrakurikuler di halaman maupun di balai desa Candirejo, maka unutk kegiatan ekstrakurikuler tari, pencak silat dan rebana dilaksanakan di dalam kelas. Tempat pelaksanaan ekstrakurikuler renang dilaksanakan di tempat lain karena tidak memiliki kolam renang sendiri. Tempat penyimpanan alatalat berada di lemari dan gudang.

Berdasarkan data tersebut diketahui bahwa solusi yang diambil SDN Candirejo Kabupaten Semarang untuk mengatasi keterbatasan sarana prasarana sesuai dengan Panduan Teknik Ekstrakurikuler di SD yaitu tempat kegiatan: sekolah/madrasah sendiri, dan atau sekolah/madrasah yang menyelenggarakan kegiatan yang sama, dan atau tempat lain; Peralatan yang digunakan disesuaikan dengan jenis kegiatan (Kemendikbud, 2016).

\subsection{Pengelolaan Ketenagaan}

Berdasarkan wawancara dan studi dokumentasi bahwa pada bidang ketenagaan yang terlibat dalam program ekstrakurikuler antara lain kepala sekolah sebagai penanggung jawab keseluruhan di sekolah, 1 guru penanggungjawab ekstrakurikuler, dan 1 pelatih dan pendamping. Kepala sekolah ikut berpartisipasi dan mengontrol program ekstrakurikuler. Kepala sekolah juga mengeluarkan kebijakan jika ada hal yang perlu dilakukan oleh sekolah untuk meningkatkan mutu program.

Kepala sekolah membimbing penanggungjawab dan guru pendamping ekstrakurikuler dari perencanaan, pelaksanaan, hingga memberi masukan berdasarkan produk yang dihasilkan dari sebuah program. Penanggung jawab dan guru pendamping atau pelatih saling berkoordinasi agar program ekstrakurikuler dapat terlaksana dengan lancar. Ekstrakurikuler yang dibimbing oleh pelatih dari luar karena membutuhkan pelatih yang berkompeten di bidangnya adalah ekstrakurikuler drum band dan pencak silat. Masing-masing peanggungjawab dan pelatih sudah melaksanakan tugasnya sesuai dengan fungsi-fungsinya.

Hal tersebut sudah sesuai dengan Panduan Teknis Ekstrakuirkuler (Kemendikbud, 2016) di SD bahwa a. Kepala Sekolah : (1) Bertanggung jawab secara formal operasional dalam keseluruhan program melalui kegiatan ekstrakurikuler, (2) Menetapkan kebijakan yang berkaitan dengan kegiatan ekstrakurikuler, (3) Memberikan arahan kepada, pembimbing ekstrakurikuler, dan stakeholder sekolah yang lain terkait dengan kegiatan ekstrakurikuler, (4) Memantau pelaksanaan kegiatan ekstrakurikuler, (5) Memantau pelaksanaan pembimbingan kegiatan ekstrakurikuler, (6) Melaporkan dan mempertanggungjawabkan program kegiatan ekstrakurikuler kepada stakeholder; b. Pembimbing Kegiatan Ektrakurikuler: (1) Menyusun program kegiatan ekstrakurikuler yang dibina, (2) Melaksanakan program kegiatan ekstrakurikuler yang dibina, (3) Melakukan evaluasi program kegiatan ekstrakurikuler yang dibina, (4) Memantau kemajuan yang dicapai oleh peserta didik yang mengikuti kegiatan ekstrakurikuler yang dibimbingnya, (5) Bekerja sama dengan orang tua peserta didik dalam berbagai kegiatan ekstrakurikuler; c. Pengawas Sekolah: (1) Memantau dan melakukan pengawasan terhadap program kegiatan ekstrakurikuler di lingkungan 
Winny Rosa Damayanti, Yari Dwikurnaningsih

EVALUASI PROGRAM EKSTRAKURIKULER DI SDN CANDIREJO KABUPATEN SEMARANG

REFLEKSI EDUKATIKA : Jurnal Ilmiah Kependidikan, Volume 11, Nomor 1, Desember 2020, hlm. 59-69

sekolah binaannya, (2) Melakukan pembinaan terhadap kepala sekolah sekolah dan guru di lingkungan sekolah binaannya, terkait dengan pelaksanaan kegiatan ekstrakurikuler, (3) Mempertanggungjawabkan kegiatan pemantauan, pengawasan, dan pembinaan dalam kegiatan ekstrakurikuler di lingkungan sekolah binaannya kepada kepala UPTD dan dinas pendidikan kabupaten/kota; d. Komite Sekolah/Orangtua Siswa: (1) Mengawal proses perencanaan, pelaksanaan, dan evaluasi kegiatan ekstrakurikuler yang dilakukan oleh kepala sekolah, wakil kepala sekolah, dan guru pembina ekstrakurikuler, (2) Menjembatani aspirasi orangtua dan masyarakat terkait kegiatan ekstrakurikuler.

Sejalan dengan penelitian Viningsih (2013) mengenai kompetensi pembimbing atau pelatih dalam melatih ekstrakurikuler bahwa persepsi peserta didik terhadap pelaksanaan dinilai dari aspek: (1) Ketersediaan guru pembimbing/pelatih untuk kegiatan ekstrakurikuler sesuai dengan yang dibutuhkan dengan skor 62\% (baik); (2) Mengatasi jumlah guru pembimbing yang kurang sesuai dengan yang dibutuhkan diusahakan dengan menugaskan guru lain untuk membimbing meskipun kurang sesuai dengan kemampuannya dengan skor $76 \%$ (baik); dan (3) Kemampuan guru pembimbing untuk membimbing dinyatakan mampu dengan skor 42\% (cukup baik).

Berdasarkan paparan tersebut dapat diketahui bahwa pengelolaan ketenagaan sesuai dengan Panduan Teknis Kegiatan Ekstrakurikuler di SD dimana pihak yang terlibat menjalankan tanggung jawabnya. Keterlibatan komite SDN Candirejo Kabupaten Semarang perlu ditingkatkan dalam proses monitoring pelaksanaan program esktrakurikuler di SDN Candirejo Kabupaten Semarang.

\subsection{Pengelolaan Pembiayaan}

Pada bidang pengelolaan pembiayaan, SDN Candirejo mengalokasikan dana BOS untuk pembelajaran dan ekstrakurikuler. SDN Candirejo Kabupaten Semarang tidak memungut biaya dari orang tua/wali murid, komite, maupun pihak lain. Sekolah mengelola sebaik mungkin dana yang dialokasikan untuk ekstrakurikuler. Berdasarkan studi dokumentasi dapat diketahui bahwa pengelolaan dana untuk program ekstrakurikuler sesuai dengan Panduan Teknis Ekstrakurikuler di SD bahwa anggaran diperlukan untuk kegiatan yang disusun (Kemendikbud, 2016) dan dana diperoleh dari sumber-sumber yang sesuai dengan aturan perundang-undangan (Kemendikbud, 2016).

\section{Evaluasi Produk Ekstrakurikuler}

Produk program ekstrakurikuler dapat dilihat dari laporan hasil belajar peserta didik atau rapor pada muatan pelajaran SBdP, PJOK dan nilai pengembangan diri pada aspek ekstrakurikuler. Terdapat peningkatan nilai keterampilan muatan pelajaran SBdP dan PJOK pada rapor peserta didik. Peserta didik yang mengikuti ekstrakurikuler yang berkaitan dengan materi yang ada pada muatan pelajaran SBdP dan PJOK lebih menguasai karena sudah terlatih ketika kegiatan ekstrakurikuler.

Adanya peningkatan keterampilan non akademik dan perkembangan softskill peserta didik yang dapat dilihat pada dokumen laporan hasil belajar peserta didik aspek penilaian pengembangan diri peserta didik. Perkembangan sikap peserta didik dapat dilihat di laporan hasil belajar peserta didik pada aspek Kompetensi Inti 1 dan Kompetensi Inti 2. Peserta didik memiliki kepercayaan diri ketika menampilkan pertunjukkan di depan umum, yaitu tampil di acara atau perlombaan. Selain itu perkembangan perilaku positif yang ditunjukkan dalam kehidupan seharihari. Dengan mengikuti ekstrakurikuler diharapkan peserta didik mendapatkan bekal untuk masa depan peserta didik. Pada tahun 2020, SDN Candirejo Kabupaten Semarang berhasil meraih Juara I lomba pencak silat putri POPDA Kabupaten Semarang dan juara I lomba pencak silat putra POPDA Kabupaten Semarang, Juara Harapan III Pesta Siaga Putra.

Sejalan dengan penelitian Annu dan Sunita (2014) bahwa ekstrkurikuler memiliki efek positif pada kehidupan peserta didik dengan memperbaiki perilaku, prestasi sekolah, penyelesaian sekolah, aspek positif untuk membuat orang dewasa sukses, dan aspek sosial. Penelitian lain Elklisly (2017) menyebut bahwa manfaat ekstrakurikuler yang diperoleh peserta didik adalah keterampilan profesional, kepemimpinan, manajemen waktu, fleksibilitas, dan keterampilan lainnya.

Dampak untuk SDN Candirejo Kabupaten Semarang dari penyelenggaraan program ekstrakurikuler adalah untuk peserta SDN Candirejo Kabupaten Semarang menerima permintaan untuk menampilkan di berbagai acara, misalnya wisuda dan perpisahan pondok pesantren dan acara di kecamatan atau kelurahan. Selain itu dapat menjadi media promosi. Setiap penerimaan peserta didik baru, SDN Candirejo Kabupaten Semarang mendapatkan jumlah peserta didik dengan rata-rata 35 peserta didik. 
Winny Rosa Damayanti, Yari Dwikurnaningsih

EVALUASI PROGRAM EKSTRAKURIKULER DI SDN CANDIREJO KABUPATEN SEMARANG

REFLEKSI EDUKATIKA : Jurnal Ilmiah Kependidikan, Volume 11, Nomor 1, Desember 2020, hlm. 59-69

\section{Faktor Pendukung dan Penghambat Ekstrakurikuler}

Faktor pendukung program ekstrakurikuler SDN Candirejo Kabupaten Semarang antara lain kerjasama, komitmen untuk meningkatkan kualitas peserta didik. Transaparansi atau keterbukaan antar anggota, SDM yang berkompeten, Potensi Sumber Daya Manusia atau SDM. Faktor-faktor tersebut sangat diberdayakan untuk meningkatkan kualitas program ekstrakurikuler sehingga SDN Candirejo Kabupaten Semarang dapat mencapai target. Sedangkan faktor penghambat program ekstrakurikuler SDN Candirejo Kabupaten Semarang adalah lain kurangnya mitra yang terjalin dengan SDN Candirejo Kabupaten Semarang, belum terdapat ruang khusus ekstrakurikuler dan penyimpanan sarana ekstrakurikuler. Perlu adanya perluasan mitra agar program ekstrakurikuler dapat berjalan dengan sukses dan dapat menjadi media promosi yang efektif bagi SDN Candirejo Kabupaten Semarang.

\section{SIMPULAN}

1. Konteks Program Ekstrakurikuler Evaluasi aspek konteks program ekstrakurikuler di SDN Candirejo Kabupaten Semarang sesuai dengan Panduan Teknis Ekstrakurikuler di SD dan teori. Latar belakang program esktrakurikuler SDN Candirejo Kabupaten Semarang yaitu kesadaran atas kewajiban sekolah untuk melaksanakan pendidikan yang dapat mengembangkan potensi sesuai dengan karakteristik peserta didik. Sekolah memiliki tugas untuk membekali pengetahuan dan keterampilan bidang akademik dan non akademik pada peserta didik sehingga diperlukan adanya suatu program untuk memfasilitasi, menggali dan mengembangkan potensi, bakat dan minat peserta didik di sekolah yaitu melalui ekstrakurikuler.Tujuan program ekstrakurikulerSDN Candirejo Kabupaten Semarang bahwa untuk memfasilitasi dan mengembangkan potensi peserta didik sehingga dapat dilihat kualitas bukan hanya dari akademik tetapi juga bidang non akademik. Sasaran program ekstrakurikuler adalah peserta didik.

2. Input Program Ekstrakurikuler

Program ekstrakurikuler di SDN Candirejo Kabupaten Semarang dari aspek input sudah sesuai dengan Pedoman Teknis Ekstrakurikuler di SD. SDN Candirejo
Kabupaten Semarang hanya perlu memenuhi sarana prasarana yang kurang. Perlu meningkatkan fungsi pengawasan dan pendampingan komite sekolah terhadap penyelenggaraan program ekstrakurikuler Keempat bidang yaitu perencanaan, sumber daya manusia yang terlibat, pembiayaan dan sarana prasarana secara garis besar sudah memadai.

3. Proses Program Ekstrakurikuler

Pelaksanaan program ekstrakurikuler meliputi mekanisme program, pelaksananaan program, pengelolaan sarana prasarana, ketenagaan dan pembiayaan telah diselenggarakan sesuai dengan perencanaan program yang disusun yang mengacu pada Panduan Teknis Ekstrakurikuler di SD.

4. Produk Program Ekstrakurikuler

Produk program esktrakurikuler adalah (1) meningkatnya nilai keterampilan dan keterampilan pengembangan peserta didik yang dituangkan dalam laporan hasil belajar peserta didik SDN Candirejo Kabupaten Semarang, (2) meningkatnya kepibadian yang positif yang dituangkan dalam rapor peserta didik untuk penilaian KI 2, (3) SDN Candirejo berhasil meraih kejuaraan di perlombaan pencak silat dan pramuka pada tahun 2020. Dampak muncul dengan adanya programekstrakurikuler adalaha (1) Sering mendapatkan permintaan untuk menampilkan di beberapa acara seperti perpisahan pondok pesantren, kecamatan dan kelurahan setempat, (2) Menerima rata-rata 35 peserta didik baru setiap tahunnya karena ekstrakurikuler menjadi media promosi SDN Candirejo Kabupaten Semarang.

5. Faktor Pendukung dan Pengambat

Faktor pendukung penyelenggaraan program ekstrakruikuler di SDN Candirejo Kabupaten Semarang adalah (1) Kerjasama yang terjalin antar anggota, (2) Memiliki komitmen untuk meningkatkan kualitas peserta didik baik bidang akademik dan non akademik, (3) Transaparansi atau keterbukaan antar anggota, (4) SDM yang berkompeten, (5) Potensi Sumber Daya Manusia atau SDM (tenaga pendidik dan tenaga kependidikan, peserta didik, komite sekolah dan orang tua/wali murid) sarana prasarana dan anggaran yang memadai sehingga dapat menunjang pelaksanaan program ekstrakurikuler di SDN Candirejo Kabupaten Semarang. 
Winny Rosa Damayanti, Yari Dwikurnaningsih

EVALUASI PROGRAM EKSTRAKURIKULER DI SDN CANDIREJO KABUPATEN SEMARANG

REFLEKSI EDUKATIKA : Jurnal Ilmiah Kependidikan, Volume 11, Nomor 1, Desember 2020, hlm. 59-69

Sedangkan faktor penghambat penyelenggaraan program ekstrakurikuler di SDN Candirejo Kabupaten Semarang adalah (1) Kurangnya mitra yang terjalin dengan SDN Candirejo Kabupaten Semarang, dengan kata lain mitra yang terbatas, (2) Belum terdapat ruang khusus untuk ekstrakurikuler dan penyimpanan sarana ekstrakurikuler.

\section{REKOMENDASI}

Berdasarkan simpulan tersebut, beberapa hal yang dapat dijadikan sebagai rekomendasi adalah:

1. Penelitian evaluasi model CIPP ini, dimana mengevaluasi konteks, input, proses dan produk, dapat dijadikan sebagai referensi dalam mengevaluasi program ekstrakurikuler.

2. Pihak sekolah perlu meningkatkan kemitraan dengan pihak lain untuk meningkatkan kualitas dari program yang diselenggarakan dan memperluas jaringan sebagai media promosi sekolah.

3. Perlu dibuatkan ruang khusus untuk tempat penyimpanan sarana ekstrakurikuler.

4. Keikutsertaan komite sekolah harus lebih aktif untuk memonitoring dan mengevaluasi program yang dilaksanakan.

\section{DAFTAR PUSTAKA}

Alfiana, Rizky., Djariyo, dan Artharina, Filia Prima. 2017. Analisis Kegiatan Ekstrakurikuler Membatik Terhadap Kemampuan Membatik Seni Rupa Siswa Sekolah Dasar Di Desa Mantingan, Kecamatan Jaken, Kabupaten Pati. REFLEKSI EDUKATIKA : Jurnal Ilmiah Kependidikan, 8 (1): 43-47.

Ardianti, Sekar Dwi., Wanabuliandari, Savitri., dan Kanzunnudin, Mohammad. Implementasi Pembelajaran Berbasis Ethno-Edutainment Untuk Meningkatkan Karakter Cinta Tanah Air Siswa Sekolah Dasar. REFLEKSI EDUKATIKA : Jurnal Ilmiah Kependidikan, 9 (2): 204-209.

Arikunto, S., dan Jabar, C., S., A. 2014. Evaluasi Program Pendidikan. Jakarta: Bumi Aksara.
Baharuddin, Afid. 2014. Pengelolaan Ekstrakurikuler Peserta didik. Jurnal Manajemen Pendidikan.

Fischer, Natalie and Theis, Désirée. 2014. Quality Of Extracurricular Activities -Considering Developmental Changes In The Impact On School Attachment And Achievement. Journal for Educational Research.

Hanafi, Ahmat., et al. 2020. Manajemen Kegiatan Ekstrakurikuler Broadcasting Dalam Meningkatkan Kreativitas Peserta Didik. Jurnal Administrasi dan Manajemen Pendidikan.

Ismaya, Erik Aditia. 2012. Mencetak Generasi Emas Yang Bermental dan Berkepribadian Baik Melalui Pendidikan Kepramukaan di Ambalan Jodhipati-Candrasari. Prosiding Seminar Nasional "Merajut Generasi Emas Indonesia", Sabtu 15 September 2012 di Universitas Muria Kudus. Kudus: Badan Penerbit Universitas Muria Kudus.

Ismaya, Erik Aditia. 2013. Gerakan Pramuka Sebagai Center of Youth Leadership Training dalam Upaya Menyongsong Generasi Emas Indonesia 2045. Prosiding Konferensi Nasional Pendidikan Anak Usia Dini dan Pendidikan Dasar Tahun 2013. Bandung: Universitas Pendidikan Indonesia.

Ismaya, Erik Aditia dan Romadlon, Farid Noor 2017. Strategi Membentuk Karakter Semangat Kebangsaan Anggota Ambalan Kyai Mojo Dan Nyi Ageng Serang. REFLEKSI EDUKATIKA : Jurnal Ilmiah Kependidikan, 7 (2): 140-144.

Kemendikbud. 2016. Panduan Teknis Kegiatan Ekstrakurikuler Sekolah Dasar.

Latifah, R., N., et al. 2017. Manajemen Kegiatan Ekstrakurikuler Bahasa Inggris di SMK Negeri 7 Semarang. Educational Management.

Munastiwi, Erni. 2018. Manajemen Ekstrakurikuler Pendidikan Anak Usia Dini (PAUD). Jurnal Manageria: Jurnal Manajemen Pendidikan Islam. 
Winny Rosa Damayanti, Yari Dwikurnaningsih

EVALUASI PROGRAM EKSTRAKURIKULER DI SDN CANDIREJO KABUPATEN SEMARANG

REFLEKSI EDUKATIKA : Jurnal Ilmiah Kependidikan, Volume 11, Nomor 1, Desember 2020, hlm. 59-69

Niyra Tawfik Elklisly. 2017. The Impact of Extracurricular Activities in Egyptian Colleges on the Job Market. URJe - The Undergraduate Research Journal

Nurcahyo, Fathan. 2013. Pengelolaan Dan Pengembangan Kegiatan Ekstrakurikuler Olahraga Di SMA/MAN/Sederajat SeKabupaten Sleman. Jurnal Pendidikan Jasmani Indonesia, 9 (2).

Permendikbud Nomor 62 Tahun 2014 Tentang Kegiatan Ekstrakurikuler.

Ramdhoni, Siti. 2019. Evaluasi Kegiatan Ekstrakurikuler Pramuka Dalam Meningkatkan Karakter Siswa. Edulead: Journal of Education Management.

Riitta-Leena Metsäpelto and Lea Pulkkinen. 2014. The benefits of extracurricular activities for socioemotional behavior and school achievement in middle childhood: An overview of the research. Journal für Bildungsforschung Online, 6 (3).
Singh Annu and Mishra Sunita. 2015. Extracurricular Activities And Student's Performance In Secondary School Of Government And Private Schools. International Journal of Sociology and Anthropology Research, 1 (1)

Sugiyono. 2015. Metode Penelitian Pendidikan. Bandung: ALFABETA.

Sugiyono. 2016. Metode Penelitian \& Pengembangan: Research and Development. Bandung: Alfabeta.

Undang-Undang Nomor 20 Tahun 2003 Tentang Standar Pendidikan Nasional.

Viningsih, S.R. 2013. Pelaksanaan Program Pengembangan Diri siswa di SMAN I Timpeh Kec. Timpeh Kabupaten Dharmasraya. Bahana Manajemen Pendidikan.

Wirawan. 2012. Evaluasi:Teori, Model, Standar, Aplikasi, dan Profesi.Depok: PT Raja Grafindo Persada. 